\title{
A New Type of Poly(GMA) with Carbazole: Synthesis and Characterization
}

\author{
Yeni Tip Karbazollü Poli(GMA): Sentezi ve Karakterizasyonu
}

\author{
Research Article \\ Mohamad Hosein Nasirtabrizi*, Soheila Einalizadeh \\ Department of Applied Chemistry, Ardabil Branch, Islamic Azad University, Ardabil, Iran.
}

\section{A B STRACT}

\begin{abstract}
The synthesis, characterization and thermal behaviour of styrenic copolymers of glycidyl methacrylate without and with carbazole groups are reported. The copolymers based on glycidyl methacrylates belong to the potential class of functional polymers. Epoxide ring opening reaction is a route that explains the chemical modification of glycidyl methacrylate (GMA) polymers with nucleophilic reagent containing hydroxyl, carboxyl or amine groups. In this work, copolymers of GMA have been modified by incorporation of bulky carbazole groups.The homopolymer of glycidyl methacrylate (GMA) and its random copolymers with styrene, methyl styrene, methoxy styrene were synthesized by free radical polymerization using azobis(isobutyronitrile) (AIBN) as initiator at $70 \pm 1^{\circ} \mathrm{C}$. The polymers were characterized by ${ }^{1} \mathrm{H}-\mathrm{NMR}$ and IR spectroscopic techniques. This modification increases the rigidity of polymers and, subsequently, their glass transition temperature of polymer as shown by DMTA analysis. The results show that, with the incorporation of the carbazole groups in the polymer side chains, a series of novel modified polymer containing new properties are obtained, that can find some applications in polymer industry.
\end{abstract}

\section{Key Words}

Glycidyl methacrylate, Carbazole, Styrene, Ring opening, Modified polymer.

\section{öz}

\begin{abstract}
Karbazol grupları varlığında ve yokluğunda glisidil metakrilatın stirenik kopolimerlerinin sentezi, - karakterizasyonu ve ısıl davranışları rapor edilmiştir. Glisidil metakrilat temelli kopolimerler fonksiyonel polimerler sınıfına aittir. Epoksit halka açma tepkimesi, hidroksil, karboksil veya amin grupları içeren nükleofilik reaktif ile glisidil metakrilat (GMA) polimerlerinin kimyasal modifikasyonunu açıklayan bir yoldur. Bu çalışmada, GMA kopolimerleri büyük karbazol gruplarının birleşmesiyle modifiye edilmiştir. Glisidil metakrilat (GMA) homopolimeri ve stiren, metil stiren, metoksi stirenli rasgele kopolimerler $70 \pm 1^{\circ} \mathrm{C}$ 'da başlatıCı olarak azobis(izobütironitril) (AIBN) kullanılarak serbest radikal polimerizasyonu ile sentezlendi. Polimerler, ${ }^{1} \mathrm{H}-\mathrm{NMR}$ ve IR spektroskopik teknikleriyle karakterize edildi. Bu modifikasyon, polimerlerin sertliğini ve ardından DMTA analizi ile gösterilen polimerlerin camsı geçiş sıcaklığını arttırır. Sonuçlar, karbazol gruplarının polimer yan zincirlerine dahil edilmesi ile, polimer endüstrisinde bazı uygulamalar bulabilen yeni özelliklere sahip bir dizi yeni modifiye edilmiş polimer elde edildiğini göstermektedir.
\end{abstract}

\section{Anahtar Kelimeler}

Glisidil metakrilat, Karbazol, Stiren, Halka açılması, Modifiye polimer.

\footnotetext{
Article History: Received: Mar Jun 12, 2016; Revised: Sep 3, 2016; Accepted: Sep 20, 2016; Available Online: Apr 1, 2017 DOI: $10.15671 /$ HJBC.2017.157
}

Correspondence to: M. H. Nasirtabrizi, Department of Applied Chemistry, Ardabil Branch, Islamic Azad University, Ardabil, Iran. 


\section{INTRODUCTION}

2,3-Epoxypropyl methacrylate or glycidyl methacrylate (GMA) is a fascinating monomer exhibiting polymarizable methacrylic unsaturation and an oxiran function of potential reactivity [1]. Copolymers based on glycidyl methacrylate (GMA) have applications in biological drugs and biomolecules and in electronics as negative electron-beam resists materials [2]. Due to the reactive nature of the epoxy group, copolymers containing GMA have led to an interesting class of new materials. The epoxide opening reaction with nucleophiles is generally performed with acidic or basic catalysis and in the absence of such catalysts, the reaction is moderately slow [3]. This monomer has been homopolymerized and copolymerized by means of free radical initiators known to selectively attack methacrylic double bonds. There already exist examples of some interesting polymers that are modified by carbazole groups [4-6]. Carbazole is well-known hole- transporting and electroluminescence (EL) unit. Polymers containing carbazole moieties in the main chain or side chain have attracted much attention because of their unique properties, which allow various optoelectronic applications such as photoconductive, EL and photoreactive material [7-10]. Present research work describes the novel synthesis and properties of poly (GMA) and copolymers of GMA modified with carbazole. The glass transition temperature $\left(T_{q}\right)$ is an important intrinsic characteristic that influences the material properties of a polymer and its potential applications. Furthermore, polymers with high glass-transition temperatures are attractive for industrial polymer science because of strong economic rewards that may arise from their potential applications [11]. Study of thermal properties of the obtained polymers show that incorporation of bulky carbazole groups as side chains leads to stiffness of the polymer chains with increasing of thermal stability and glass transition temperature [12]. Chemical modification of polymer structures is an important method formodification of polymer properties such as mechanical, thermal and surface properties. A few numbers of polymers with pendant carbazolyl groups have been prepared [13].

As we know, there is no information about incorporation of the carbazole group to glycidyl methacrylate polymer.

\section{EXPERIMENTAL}

\section{Instrument}

The infrared spectra were recorded on Bruker spectrometer scientific 500 IR. ${ }^{1} \mathrm{H}$-NMR spectra were run on a Bruker $300 \mathrm{MHz}$ spectrometer at room temperature using chloroform-d as solvent and TMS as internal standard. Dynamic mechanical thermal analysis (DMTA) were characterized by Triton (Tritec $2000 \mathrm{DMN}$ ) with rate $5^{\circ} \mathrm{C} / \mathrm{min}$.

\section{Materials}

Carbazole obtained from Aldrich chemical company. Azobis(isobutyronitrile) (AIBN)was purchased from Merck and purified by recrystallization from absolute ethanol. Styrene, methyl styrene, methoxy styrene and glycidyl methacrylate (GMA) were obtained from Merck and distilled under reduced pressure to remove inhibitors before use. Sodium hydride $(60 \%)$ obtained from Aldrich chemical company. Tetrahydrofuran (THF) was distilled over sodium/ benzophenone.

\section{Polymerization of Glycidyl Methacrylate}

To a solution of glycidyl methacrylate $(5.6 \mathrm{~g}, 40$ $\mathrm{mmol}$ ) in $15 \mathrm{~mL}$ chloroform was added $(0.065 \mathrm{~g}, 0.4$ $\mathrm{mmol}$ ) AIBN. Polymerization studies were carried out for $24 \mathrm{~h}$ at $70^{\circ} \mathrm{C}$ whilestirring under a nitrogen atmosphere. Polymer solution were poured drop wise into a large excess of methanol. The obtained polymer were purified by precipitating twice from chloroform into methanol. Polymer were filtered and dried under vacuum at room temperature (Figure 1).

\section{Synthesis of Copolymers(I-III)}

Poly(GMA-co-St) (I), Poly(GMA-co-Metyl St) (II) and Poly(GMA-co-Metoxy St) (III) have been synthesized as a general method using1.04 $\mathrm{g}(10 \mathrm{mmol})$ of styrene(l) or $(1.19 \mathrm{~g}, 10 \mathrm{mmol})$ of methyl styrene(II) or $1.35 \mathrm{~g}(10 \mathrm{mmol})$ of 4-methoxystyrene. Also, a mixture of $4.26 \mathrm{~g}$ $(30 \mathrm{mmol})$ of GMA and $0.065 \mathrm{~g}(0.4 \mathrm{mmol})$ of AIBN in $20 \mathrm{~mL}$ of tetrahydrofouran (THF). The reaction mixture was heated to $70 \pm 1^{\circ} \mathrm{C}$ with constant stiring under a nitrogen atmosphere. The reaction conditions were maintaind for $24 \mathrm{~h}$. 
<smiles>C=C(C)C(=O)CC1CO1</smiles>

$\underset{\mathrm{AIBN}, \mathrm{Chloroform}}{\longrightarrow}$ $70^{\circ} \mathrm{C}, 24 \mathrm{~h}$

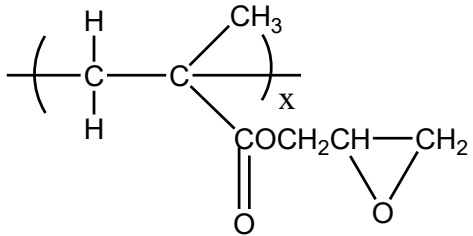

Figure 1. Polymerisation reaction of glycidyl methacrylate.

Polymer solutions were poured dropwise into a large excess of methanol. The obtained polymer was purified by precipitating twice into methanol. Polymer were filtered and dried under vacuum at room temperature. The reaction conditions are shown in Table 1 and Figure 2.

\section{$\mathbf{1}_{\mathrm{H}-\mathrm{NMR}}$ and FT-IR Spectra of Polymers I-III.}

I. FT- IR (KBr) $\vee \mathrm{cm}^{-1}: 3438,3060,2943,1727,1633$, 1602,1452, 1388, 1341, 1261, 1127, 994.1087, 906. 'H-NMR ( $\mathrm{CDCl}_{3}$, TMS, $\left.250 \mathrm{MHz}\right)$ ppm: 1.08-1.94 $(3 \mathrm{H}), 1.90-1.97(2 \mathrm{H}), 2.64(\mathrm{~m}, 1 \mathrm{H}), 2.83(\mathrm{~m}, 1 \mathrm{H}), 3.23$ $(\mathrm{m}, 1 \mathrm{H}), 3.85(\mathrm{~m}, 1 \mathrm{H}), 4.25(\mathrm{~m}, 1 \mathrm{H})$.

II. FT-IR (KBr) $v \mathrm{~cm}^{-1}: 3046$ (w), 2944 (s), 2986 $(\mathrm{w}), 1720(\mathrm{~s}), 1478(\mathrm{~s}), 1327(\mathrm{w}), 1255(\mathrm{~m}), 1153$ (s), $905(\mathrm{w})$.

${ }^{1} \mathrm{H}-\mathrm{NMR}\left(\mathrm{CDCl}_{3}, \mathrm{TMS}, 250 \mathrm{MHz}\right)$ ppm: 0.92-1.10 (9H), $1.25-1.60,1.60-1.72(\mathrm{~m}, 4 \mathrm{H}), 1.85-1.94(4 \mathrm{H})$, $2.63(\mathrm{~m}, 1 \mathrm{H}), 2.83(\mathrm{~m}, 1 \mathrm{H}), 3.21(\mathrm{~m}, 1 \mathrm{H}), 3.75(\mathrm{~m}, 1 \mathrm{H})$ $4.30(\mathrm{~m}, 1 \mathrm{H}), 4.00(\mathrm{~s}, 2 \mathrm{H})$.
III. FT-IR (KBr) $v \mathrm{~cm}^{-1}: 3046(\mathrm{w}), 2986$ (s), 2938 (s), $1720(\mathrm{~s}), 1478(\mathrm{~m}), 1327(\mathrm{w}), 1255(\mathrm{~m}), 1153$ (s), 905 (w).

${ }^{1} \mathrm{H}-\mathrm{NMR}\left(\mathrm{CDCl}_{3^{\prime}}, \mathrm{TMS}, 250 \mathrm{MHz}\right) \quad$ ppm: 0.88-1.05 $(6 \mathrm{H}), 1.46-1.90(\mathrm{~s}, 4 \mathrm{H}), 2.64(\mathrm{~m}, 1 \mathrm{H}), 2.84(\mathrm{~m}, 1 \mathrm{H})$, $3.22(\mathrm{~m}, 1 \mathrm{H}), 3.79(\mathrm{~m}, 1 \mathrm{H}), 4.31(\mathrm{~m}, 1 \mathrm{H}), 3.60(\mathrm{~s}, 3 \mathrm{H})$.

\section{Attachment of Carbazolyl Group to the Side} Chain of Homopolymer and Copolymers

Sodium hydride $(60 \mathrm{mmol}, 1.44 \mathrm{~g})$ was slowly added to carbazole $(60 \mathrm{mmol}, 10.14 \mathrm{~g})$ dissolved in $10 \mathrm{~mL}$ of THF at room temperature mixture stirring under nitrogen atmosphere for $30 \mathrm{~min}$. After this time, mixture was cooled to $-5^{\circ} \mathrm{C}$ in ice-salt mixture while vigorous stirring. Then a solution of polymer I $(7.8 \mathrm{~g}$, with $30 \mathrm{mmol}$ of epoxide containing monomer unit) or II ( $7.6 \mathrm{~g}$, with $30 \mathrm{mmol}$ of epoxide containing monomer unit) or III ( $8.2 \mathrm{~g}$, with $30 \mathrm{mmol}$ of epoxide containing monomer unit) in $20 \mathrm{ml}$ of dry THF was added drop wise within $1 \mathrm{~h}$. The contents were kept at ambient temperature for another $3 \mathrm{~h}$ while stirring. The

Table 1. The condition of preparation of copolymers I-III.

\begin{tabular}{cccccc}
\hline Sample & Monomer1 & Monomer2 & $\begin{array}{c}\text { Amount of } \\
\text { Monomer1 } \\
(\mathrm{mmol})\end{array}$ & $\begin{array}{c}\text { Amount of } \\
\text { Monomer2 } \\
(\mathrm{mmol})\end{array}$ & $\begin{array}{c}\text { Time } \\
(\mathrm{h})\end{array}$ \\
\hline $\mathrm{I}$ & GMA & St & 30 & 10 & 24 \\
\hline $\mathrm{II}$ & GMA & Metyl-St & 30 & 10 & 24 \\
\hline III & GMA & Metoxy-St & 30 & 10 & 24 \\
\hline
\end{tabular}

$[\mathrm{AlBN}]=100,[1]+[2] /[\mathrm{AlBN}]=0.04 /[1]+[2]$

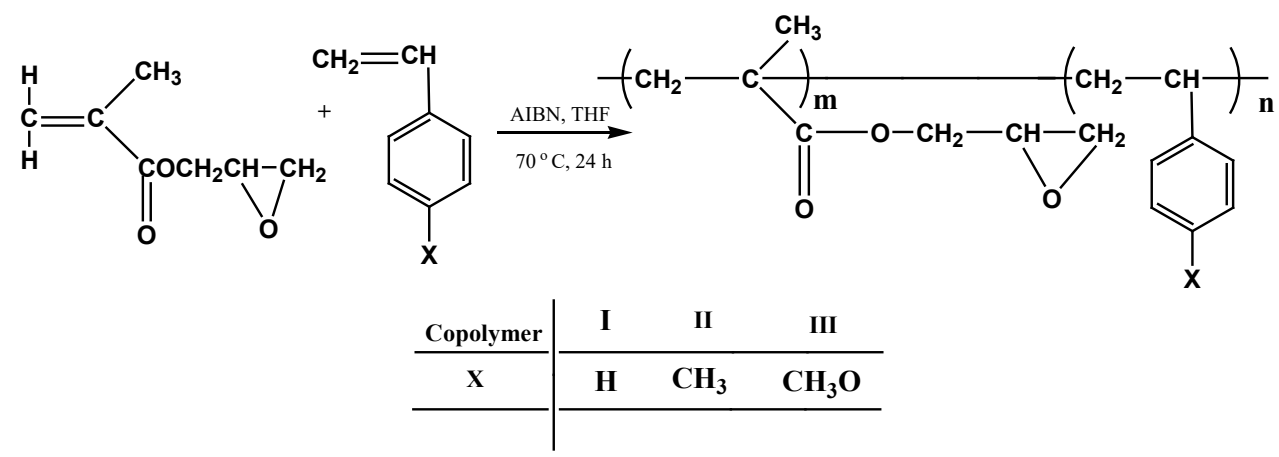

Figure 2. Polymerisation reaction of Glycidyl methacrylate and styrene. 

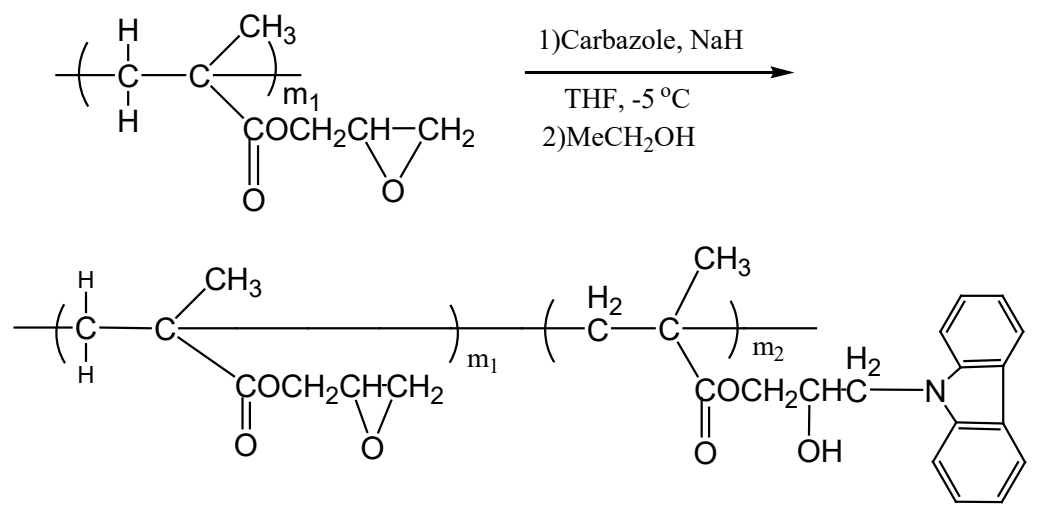

Figure 3. Carbazolyl attachment to the poly(glycidyl methacrylate).
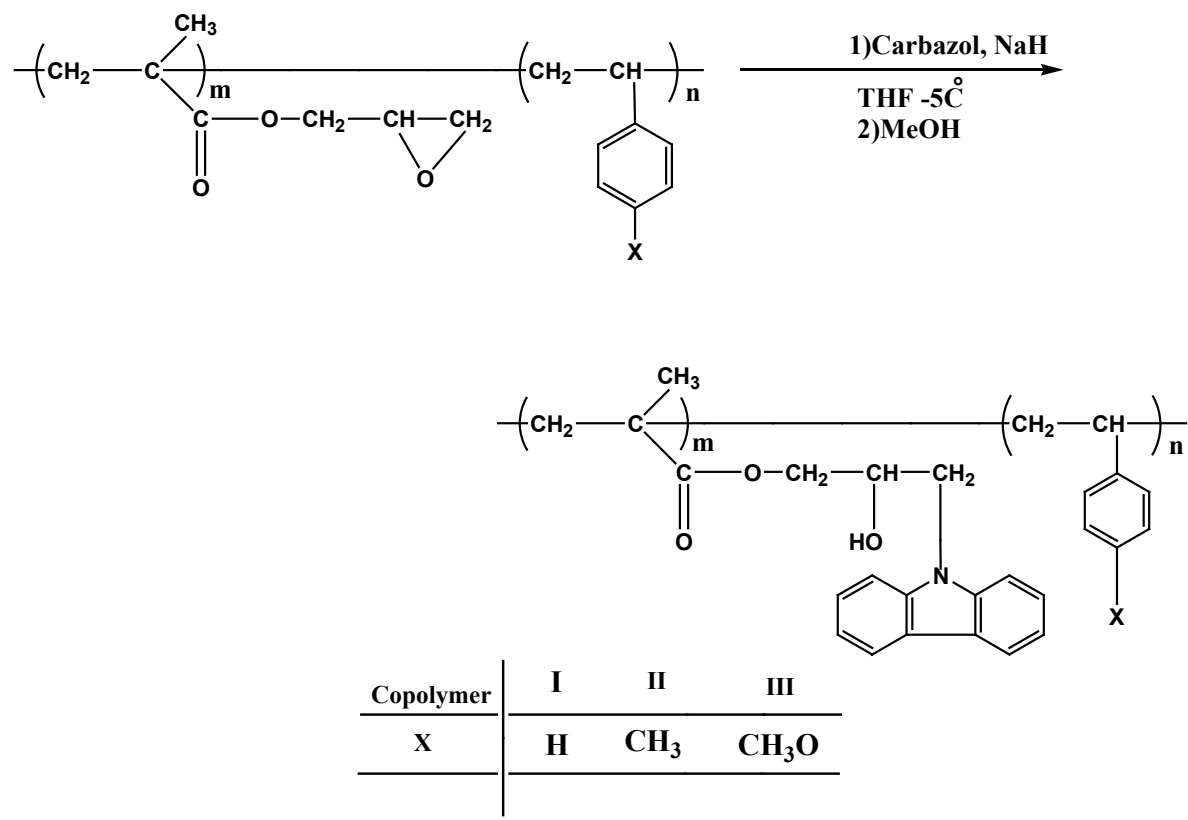

Figure 4. Carbazolyl attachment to the poly(glycidyl methacrylate-styrene).

mixture were then poured drop wise into a large excess of cold ethanol. The precipitated solid was recovered by filtration, washed successively with water, ethanol, and then dried in vacuum at room temperature for $28 \mathrm{~h}$. The reaction conditions are shown in Figures 3 and 4.

\section{${ }^{1} \mathrm{H}-$ NMR and FT-IR Spectra of Polymers I with Carbazole-III with Carbazole.}

I. FT-IR (KBr) v cm-1: 3160-3620 (br), 3040 (w), $2986(\mathrm{~m}), 2938(\mathrm{~m}), 1720(\mathrm{~s}), 1478(\mathrm{~s}), 1327(\mathrm{~m})$ $1255(\mathrm{~m}), 1153(\mathrm{~s}), 905$ (w). ${ }^{1} \mathrm{H}-\mathrm{NMR}\left(\mathrm{CDCl}_{3^{\prime}} \mathrm{TMS}_{\text {, }}\right.$ $250 \mathrm{MHz}$ ) ppm: 1.08-1.94 (3H), 1.90-1.97 (2H), 2.64 $(\mathrm{m}, 1 \mathrm{H}), 2.83(\mathrm{~m}, 1 \mathrm{H}), \quad 3.50-4.25(5 \mathrm{H}), 6.92-8.03$ $(8 \mathrm{H})$.

II. FT-IR (KBr) $\vee \mathrm{cm}^{-1}: 3250-3610(\mathrm{br}), 3040(\mathrm{w})$, $2943(\mathrm{~s}), 2858(\mathrm{w}), 1721(\mathrm{~s}), 1326(\mathrm{~m}), 1253(\mathrm{~m})$, 1156 (s). ${ }^{1} \mathrm{H}-\mathrm{NMR}\left(\mathrm{CDCl}_{3^{\prime}}\right.$ TMS, $\left.250 \mathrm{MHz}\right)$ ppm:
$0.92-1.10(9 H), 1.25-1.60,1.60-1.72(m, 4 H), 1.85-$ $1.94(4 \mathrm{H}), 2.63(\mathrm{~m}, 1 \mathrm{H}), 2.83(\mathrm{~m}, 1 \mathrm{H}), 3.21(\mathrm{~m}, 1 \mathrm{H})$, 3.75- $4.30(5 \mathrm{H}), 4.00(\mathrm{~s}, 2 \mathrm{H}), 6.62-8.03(8 \mathrm{H})$.

III. FT-IR (KBr) v cm-1: 3150-3640 (br), $3040(\mathrm{w})$, $2986(\mathrm{~m}), 2938(\mathrm{~s}), 1720(\mathrm{~s}), 1327(\mathrm{~m}), 1255$ (s), 1153 (s). ${ }^{1} \mathrm{H}-\mathrm{NMR}\left(\mathrm{CDCl}_{3}, \mathrm{TMS}, 250 \mathrm{MHz}\right)$ ppm: 0.88-1.05 (6H), 1.46-1.90(s, 4H), $2.64(\mathrm{~m}, 1 \mathrm{H}), 2.84$ $(\mathrm{m}, 1 \mathrm{H}), 3.22(\mathrm{~m}, 1 \mathrm{H}), 3.60(\mathrm{~s}, 3 \mathrm{H}), 3.75-4.30(5 \mathrm{H})$, $6.62-8.03(8 \mathrm{H})$.

\section{RESULTS and DISCUSSION}

The presence of oxirane group in GMA polymers and copolymers favours futher chemical modification for various application [12]. Monomer of GMA was homopolymerized and copolymerized with styrene, methyl styrene, methoxy styrene 
by free radical polymerization in solution. The chemical structure of the related polymers are represented in Figures 5 and 6 . The resulting polymers are soluble in polar aporotic solvents (e.g. dimethyl formamide, dimethyl sulphoxide, tetrahydrofuran) and chlorinated solvents (e.g. chloroform, and methylene chloride) but insoluble in hydrocarbons ( $e, g$. benzene, toluene, xylenes) an solvents containing hydroxyl groups such as methanol, ethanol and 2-propanol. The presence of the epoxy group in GMA leads to modification of poly (GMA) and copolymers for various applications. But here, we have succeeded in preparing polymers having side chains containing carbazole groups the strongly affect the properties of the polymers. The assignment of the resonance peaks in the ${ }^{1} \mathrm{H}$ NMR spectrum leads to the accurate evaluation of the content of each kind of monomeric unit incorporated into the copolymer chains.

\section{Characterization of homopolymer and copolymers I-III before and after of modification with carbazole}

\section{Infrared spectra}

The asymmetrical and symmetrical stretching due to the methyl and methylene groups (I-III) are observed at 2986 and $2938 \mathrm{~cm}^{-1}$. The band at 1720 $\mathrm{cm}^{-1}$ is attributed to the ester carbonyl stretching of GMA. Another band seen at $905 \mathrm{~cm}^{-1}$ is due to the asymmetric stretching of the epoxy group. The bands at 1153.1 and $1255.6 \mathrm{~cm}^{-1}$ is attributed to the ester $\mathrm{C}-\mathrm{O}$ stretching of GMA units. To study the modification of GMA polymers by infrared spectroscopy, the peak at $905 \mathrm{~cm}^{-1}$ corresponding to the $\mathrm{C}-\mathrm{O}$ bond of the epoxy ring was selected as the most suitable wave number (Figure $5 a$ ).

Partial modification of the copolymers is confirmed by the infrared spectrum (Figure $5 b)$. The absorbance intensity is substantially diminished at $905 \mathrm{~cm}^{-1}$, whereas a broad band appears between 3200 and $3700 \mathrm{~cm}^{-1}$, indicating alcohol formation. Band in $1327 \mathrm{~cm}^{-1}$ corresponding to $\mathrm{C}-\mathrm{N}$ band in carbazole, $\mathrm{C}-\mathrm{H}$ aromatic appears in $3040.7 \mathrm{~cm}^{-1}$. The infrared spectra of the modified products show the broad bands characteristic of the hydroxyl groups at wavenumber 3200 and $3700 \mathrm{~cm}^{-1}$, which is indicative of the ring opening reaction. A decrease in the epoxide absorbance at $905 \mathrm{~cm}^{-1}$ is clearly observed (Figure $5 \mathrm{~b}$ ).

\section{'H NMR spectra}

${ }^{1} \mathrm{H}$ NMR spectra of copolymers I-III show two signals at 4.31 and $3.79 \mathrm{ppm}$ due to the splitting of methylene protons in the $\mathrm{CH}_{2} \mathrm{O}$ - group attached to the carbonyl group of the GMA group. The

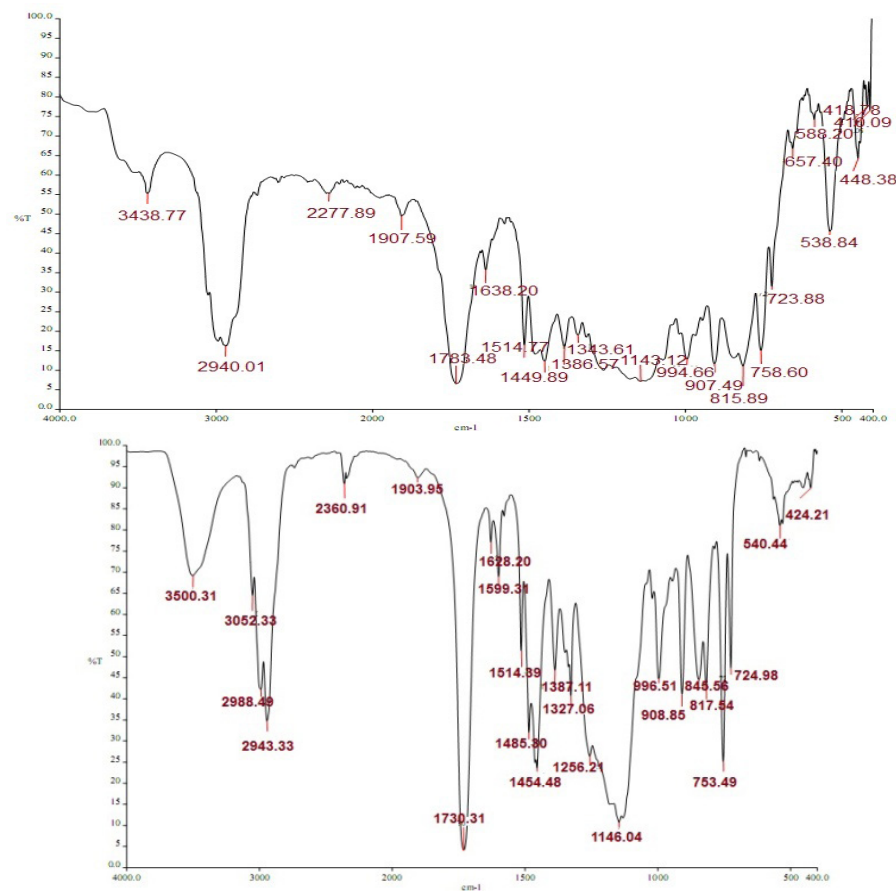

Figure 5. FTIR spectra of polymers. 


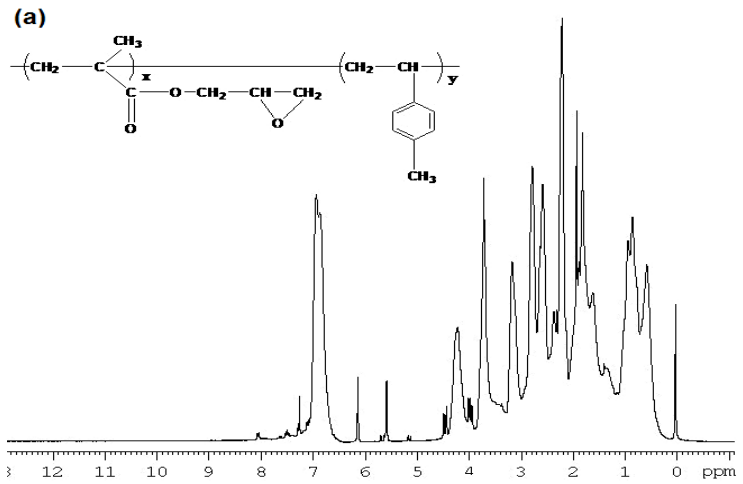

(b)

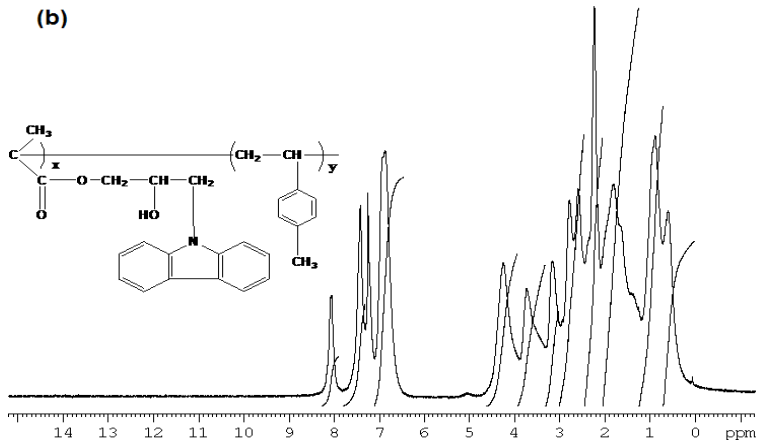

Figure 6. NMR spectra of polymers.

peack at $3.22 \mathrm{ppm}$ is due to the methyne proton of epoxy group. The methylene protons of the epoxy group show signals at 2.64 and $2.85 \mathrm{ppm}$. The broad signal at 0.89-1.89 ppm was due to the methylene groups of backbones and other alkyl groups. Three well-defined peaks, corresponding to the epoxy groups, which appear between $\delta$ $=2.64$ and $\delta=3.22 \mathrm{ppm}$ were used as references to follow the GMA polymer modification (Figure 6a). The ${ }^{1} \mathrm{H}$ NMR spectra of the pure and modified polymers show the epoxy groups ( $\delta=2.64-3.22$ $\mathrm{ppm})$, which are well defined in the unmodified polymers decrease after modification (Figure 6b).

\section{DMTA curve}

The $\mathrm{Tg}$ of polymers were determined by dynamic mechanical thermal analysis (DMTA). All the synthesized polymers show a single $\mathrm{Tg}$ showing the absence of formation of a mixture of homopolymer or the formation of a block copolymer.

DMTA scans show that the presence of bulky carbazole groups lead to an increase in the glass transition temperature from I-III copolymers.

Study of thermal properties of the obtained polymers by DMTA curves showed that the incorporation of bulky carbazolyl groups as side chains leads to stiffness of the polymer chains and increase in glass transition temperature (Figure 7).

\section{CONCLUSION}

In recent years, polymers based on glycidyl methacrylate have received increasing attention owing to their versatile applications. The present paper reports the synthesis, spectroscopic and thermal characterization of glycidyl methacrylate polymers and copolymers containing very bulky carbazole substituents as side chains. The GMA homopolymer and its copolymers with styrene methyl styrene, methoxy styrene were prepared by radical polymerization. GMA homopolymer and its copolymers containing epoxy side groups have been modified with the carbazole groups. In these cases, part of the epoxy groups are reacted. Such a dramatic reactivity decrease is likely due to the close proximity of the epoxy groups, which leads to a close packing of moieties. DMTA analyses have shown that, attachment of carbazole groups into the polymer structures causes dramatic increase in their $\mathrm{Tg}$.

(a)

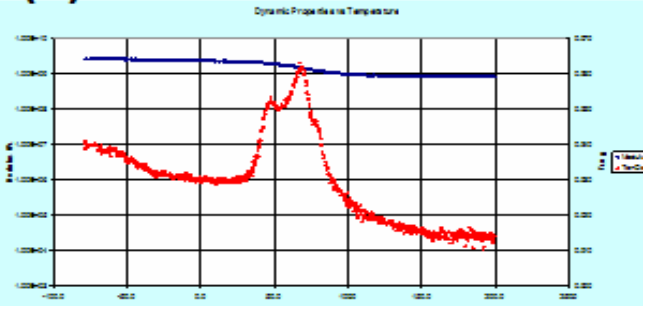

(b)

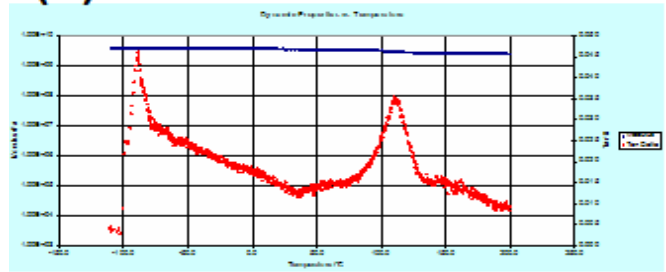

Figure 7. DMTA curves of polymers. 


\section{ACKNOWLEDGEMENTS}

The authors thank the Islamic Azad University Ardabil branch for technical supports during this research.

\section{References}

1. K.D. Safa, M.H. Nasirtabrizi, One-pot, novel chemical modification of glycidyl methacrylate copolymers, Eur. Polym. J., 41 (2005) 2310-2319.

2. J. Kala, F. Svec, V. Marousek, Reaction of epoxide groups of glycidyl methacrylate copolymers, J Polym Sci. Polym. Symp., 47 (1974) 155-166.

3. M.H. Nasirtabrizi, S. Mohebalizadeh, A. Parchehbaf Jadid, Glycidyl Methacrylate Polymers Containing Indole Groups, Iran. Polym. J., 20 (7) (2011) 579-586.

4. K.D. Safa, A.Bahadori, Sh.Tofangdarzadeh, M. H. Nasirtabrizi, Synthesis and characterization of glycidyl methacrylate polymers, J. Iran. Chem. Soc., 5 (2008) 37-47.

5. B.F. Senkal, F. Bildik, E. Yavuz, A. Sarac, Preparation of poly(glycidyl methacrylate) grafted sulfonamide based polystyrene resin, React. Funct. Polym., 67 (2007) 1471-1477.

6. Y.Tian, F. Yang, X. Yang, E. Fu, Y.Xu, Zh. Zeng, Macrocyclic polyamine-modified poly(glycidyl methacrylate-coethylene dimethacrylate), Electrophoresis, 29 (2008) 2293-2300.
7. T. Miyashita, A. Aoki, Y. Tamagawa, Effect of holetransporting film thickness on the performance of electroluminescent devices, Macromolecules, 35 (2002) 3686-3689.

8. P.A. Blanche, P.C. Lemaire, Synthesis and electrooptic properties of a new chromophore dispersed, Chem. Mater., 10 (1998) 1010-1016.

9. G.S. Liou H.W. Chen, H.J. Yen, Synthesis and photoluminescent and electrochromic properties of aromatic poly(amine amide)s bearing pendent $\mathrm{N}$-carbazolylphenyl moieties, J. Polym. Sci, Part A: Polym. Chem., 44 (2006) 4108-4121.

10. J.V. Grazulevicius, Charge-transporting polymers and Molecular glasses for optoelectronic applications, Proceeding of the 8th Polymers for Advanced Technologies, 17 (2005) 694-696

11. P.P.S. Lee, Y. Geng, H.S. Kwok, B.Z. Tang, Synthesis and light-emitting properties of poly(carbazolylacetylenes), Thin. Solid. Films., 363 (2000)149-151

12. K. Dindar Safa, M.H. Nasirtabrizi, S. Tofangdarzadeh, Synthesis and characterization of glycidyl methacrylate polymers containing tris(trimethylsilyl) methyl groups, Iran. Polym. J., 17 (2008) 1-9.

13. M.H. Nasirtabrizi, Z. Mohammadpoor Ziaei, A. Parchehbaf Jadid, Chemical modification of maleic anhydride polymers with carbazole, J. Iran. Chem. Res., 4 (2011) 59-68. 
